формы показано для аргинил-тРНК-ситтетазы из печени крыс [8] и аспарагил-тРНКсинтетазы из Ішитовидной железы свиньи [9]. Отсутствие ассоциированной формы гейРС печени может быть связано с меньшей стабнльностью АРСазиого комплекса либо с невозможностью тестировать его в данных экспериментальных условия. Дальнейшие Iсстедования иалрав.лены на вылснеппе этых вопросов.

\title{
PURIFICATION AND PROPERTIES OF LEUCY'L-IRNA-SYNTHETASE FROM THE MAMMALIAN TISSUES
}

\section{L. Ivanov, R. R. Stapulionis, L. J. Lukoševičius}

Medical Institute, Kaunas

Sum mary

The method of purification of leucyl-tRNA-synthetase (LeuRS) from rabbit liver and pig myocardium is described. Two forms $\left(E_{1}\right.$ and $\left.E_{2}\right)$ of LeuRS are distinguished by liydroxylapatite chromatography of partially purified enzvne from pig myocardium. The molecular mass was calculated to be 185000 for LeuRS from rabbit liver and 158000 for $\mathrm{E}_{\mathrm{i}}$ from pig myocardium. $E_{2}$ is stated to contain aminoacyl-tRNA synthetase activities of other amino acid specificities and is a complex of enzymes with molecular mass of about 800000 .

1. Joachimiak A., Barciszewski J. Amino acid: tRNA ligases (EC 6.1.1.).-FEBS Lelt, $1980,119, \mathrm{~N} 2$, p. $201-211$.

2. Boldenение и характеристика тейцил-тРНК-синтетазы из молочной желсзы коров / О. И. Гудзера, А. В. Ельская, Г. В. Овчаренко и др.-Молекуляр. биология, 1979, 13, № 3 , c. $550-557$.

3. Hedrick J. L., Smith A.J. Estimation of molecular weight by polyacrylamide gel electrophorcsis.-Arch. Biochem. and Biophys., 1968, 126, N I, p. 155-164.

4. Purification of leucyl transfer ribonucleic acid synthetase from Escherichia coli / H. Hayashi, J. R. Knowles, J. R. Katze et al.-J. Biol. Chem., 1970, 245, N 6, p. 14011406.

5. Корнищ-Бодуен Э. Основы ферментативной кинетики.-М.: Мир, 1979.-280 с.

6. Legocki A. B., Pawelkiewicz J. Amino acid activating enzymes in yellow lupin seeds, and purification on leucyl-tRNA synthetase.- Acta biochim. pol., 1967, 14, N 3, p. $3131-3138$.

7. Dang C. V., Johnson D. L., Vang D. C. H. Higl molecular mass amino acyl-tRNA synthetase complexes in eukaryotes.-FEBS Lett., 1982, 142, N 1, p. 1-6.

8. Deutcher M. P., Ni R. C. Purification of a low molecular weight form of rat liver arginyl-tRNA synthetasc.-J. Biol. Chem., 1982, 257, N 11, p. 6003-6006.

9. Vellekamp G. J., Kull F. J. Allotropism of aspartyl-tRNA-synthetase from porcine thyroid.-Eur. J. Biochem., 1981, 118, N 2, p. $261-269$.

Каунас. мел. ин-т

Получено 26.10.84

УДК $575.113 .576 .851 .5: 576.851 .48$

\section{ИЗУЧЕНИЕ ОРГАНИЗАЦИИ ЛИЗИНОВОГО ОПЕРОНА У BACILLUS SUBTILIS}

\section{3. М. Алексиева, Т. Н. ІІІевченко, С. С. Малюта}

Биосинтез лизина у микроорганизмов осуществляется в девять стадий [1]. Наиболее полно организация оперона биосинтеза лизина и регуляция его экспрессии изучена у E. coli. Лизиновые гены у этого вида микроорганизмов расположены в нескольких об.астях хромосомы [2], не образуя единой группы сцепления. Чрезвычайно мало данных о структуре лизинового оперона Bacillus subtilis - вида микроорганизмов, широко используемого в микробиологической промышленности для получения биологически активных метаболитов. Ранее нами были клонированы Sall-, BgllI-фрагменты ДНK B. subtilis, содержапие ряд генов биосинтеза лизина $[3,4]$. Однако рекомбинантные плазмиды pLRS33 и pLRB4, содержашие эти гены, несли также регуляторную область опе- 
рона биосинтеза рибофлавина $B$. subtilis. Поэтому пами была предпринята попытка, нспользуя рестриктазу $B a m H I$, скопструнровать плазмиду с лнзиновыми генами $B$. sub. tilis, но не содержащую части рибофлавинового оперопа.

Для создания такой рекомбипантной плазмнды исиользовали стан,цартые методики рестрикции и лигирования [5]. ДНК штамма B. subtilis ribO 3,35 обрабатывали эाдонуклеазой $B a m H I$ и лигировали с рестрицированной эти же ферментом птазмидой pBR322. Затем трансформировали штамм $E$. coli 5491 (lysA), ауксотрофный по лизину и несущий мутацию в гене, кодируюшем последний фермент биосинтеза лизина - диаминопимелат декарбоксилазу (ДАП).

Селекцию трансформантов, содержащих гибридную плазмиду, проводили на чашках, не содержащих лизнн, в присутствин ампициллина (25 мкК/ М.T).

Нами было получено и проанализировано несґолько гибридных клонов. Электрофоретический анализ трансформантов показал, что они содержат плазмидиую ДНК. На рисунке приведена электрофорсграмма выделениой рекомбинантной плазмид-

Электрофорсграмма плазмиды $p L B 1:$ ДНК фага $\lambda$, рестрицированная ECoRI (величина фрагментов сверху вниз: 13,$7 ; 4,7 ; 3,7 ; 3 ; 2,1 \cdot 10^{6}$.) (a); векториая плазмида $p B R 322$, рестрицированяая BamHI (б); pLBI, рестрицированная $\operatorname{BamHI}(\theta)$; гибрндпая плазмида $p L B I$ без рестрикции (2).

Fig. 1. Electrophoregram of the $p L B I$ plasmid: EcoRI-restricted $\lambda$ phage DNA (the size of fragments from top to bottom: $13.7,4.7,3.7,3$ and $\left.2.1 \cdot 10^{6}\right)(a)$; the $B a m H I$-restricted vector $p B R 322$ plasmid $(\sigma)$; Bam $B /$-restricted $p L B I(B)$; unrestricted hybrid $p L B I$ plasmid (2).

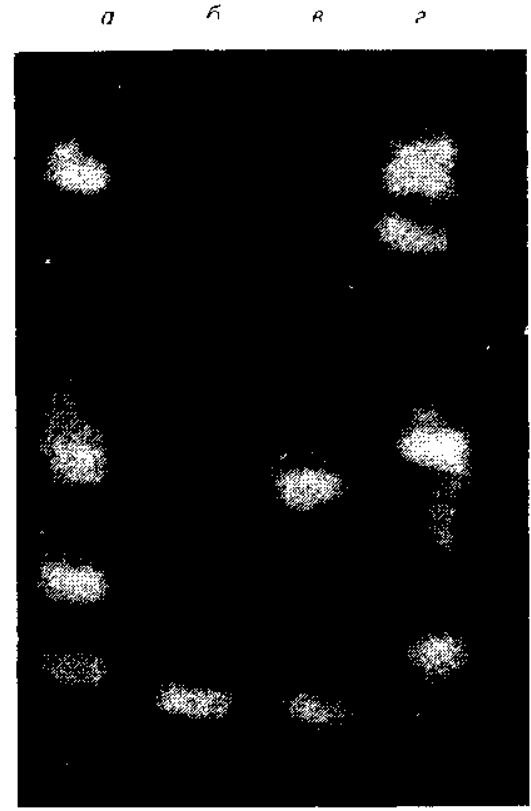

¡юй ДНҚ. Рестриктаза BamHI расщепляет плазмиду, обозначенігую нами $p L B 1$, на два фрагмента: $2,6 \cdot 10^{6}$, соответствующий нсходной плазмидс $p B R 322$ и $4,5 \cdot 10^{\mathbf{3}}$ - фрагмент LHН B. subtilis. Плазмида $p L B 1$ оказалась способной трапсформировать к иизиниезависимостп штаммы $B$. subtilis: lys42, lys21, lys3 " lys10-мутантные по синтезу лизина. Среди ly's+трансформантов нами не были обнаружены колонии, обладаюпне флюоресценцией в Ј’ $Ф$-свете, т. е. плазмида не содержала операторную область рибофлавиsового оперона B. subtilis. Для уточнения числа лизиновых генов, кіонированных на юбридной плазмиде, мы трансформировали штаммы E.coli, мутаптные по разным лизиновым генам. Плазмида $p L B 1$ способна комплементировать мутации $d a p A, d a p B$, dapC, dapD, dapE, lysA, lys y E. coli. Таким образом, рекомбинантная плазмида $p L B I$ содержит семь генов биосинтеза лизина $B$. subtilis, что свидетельствует о спепіенпом расположеІии этих генов па хромосомс. Выявляется четкое различие в оргапизации лизиновых оперонов у E. coli и B. subtilis.

Введение плазмиды $p L B I$ в штамм E. coli 5183 сопровождается повышением уровня синтеза лизина и ДАП приблизительно в два раза по сравненню с бесп:тазмидным IIT амMOM.

Таким образом, сконструированная нами плазмида $p L B I$ по рялу характеристик является более удобной для изучения оперона биосиитеза лизина у B. subtilis. Прежде всего, при меньшей величине вставки она несет бо́льшее число лизиновых генов, чем плазмида pLRS33 [3, 4], а также не содержит области регулятора оперона бносинуеза рибофлавина. 


\title{
A STUDY OF LYSINE OPERON ORGANIZATION IN BACILLUS SUBTILIS
}

Z. M. Aleksieva, T. N. Shevchenko, S. S. Malyuta

Institute of Molecular Biology and Genetics, Academy of

Sciences of the Ukrainian SSR, Kiev

S u m m a r y

The pBR322 plasmid was used for constructing $p L B 1$ plasmid carrying genes of Bacillus subtilis lysine biosynthesis. B. subtilis and E. coli strains (lysine-auxotrophs) are transformed. The plasmid is shown to complement both mutations in seven genes of lysine biosynthesis in E. coli cells and four mutations in $B$. subtilis. The size of DNA insertion, according to the elctrophoresis data, is $4,5 \cdot 10^{6}$.

1. Umbarger H. E. Amino acid biosynthesis and its regulation.-Annu. Rev. Biochem., 1978,47 , p. $533-606$.

2. Bachmann B.J., Low K. B. Linkage map of Escherichia coli K-12.-Microbiol. Revs., $1980,44, \mathrm{~N} 1$, p. $1-56$.

3. Окунев О. В., Шевченко Т. Н., Малюта С. С. Қлонирование фрагмента ДНК Ваcillus subtilis, содержащего гены биосинтеза лизина и рибофлавина.-Генетика, 1984,20, № 7 , c. $1061-1066$.

4. Экспресcия генов биосинтеза лизина Bacillus subtilis в клетках Escherichia coli/ Т. Н. Шевченко, О. В. Окунев, З. М. Алексиева, С. С. Малюта.-Цитология и генетика, 1984,18 , № 1 , с. $58-74$.

5. Improvement of Escherichia coli strains overproducing lysine using recombinant DNA techniques / B. D. Beverend, A. M. Boitel, A. M. Deschamps et al.- Eur. J. Appl. Microbiol., $1982,15, \mathrm{~N} \mathrm{2}$, p. $227-231$.

Ин-т молекуляр. биологии и генетики

АН УССР, Киев

Получено 19.10 .84

УДК $577.112 .5: 578.841$

\section{АМИНОКИСЛОТНАЯ ПОСЛЕДОВАТЕЛЬНОСТЬ ФРАГМЕНТОВ ПОЛИПЕПТИДНОЙ ЦЕПИ ГРАНУЛИНА ВИРУСА ГРАНУЛЕЗА ОЗИМОЙ СОВКИ, AGROTIS SEGETUM}

\author{
Э. А. Ковлов, Т. Л. Левитина, Н. В. Роднин, \\ В. М. Харченко, С. Б. Серебряный
}

В предыдущем сообшении [1] обсуждались результаты сравнителыгого исследования физико-химических свойств полиэдрина вируса ядерного полиэдроза (ВЯП) и гранулина вируса гранулеза (ВГ) A. segetum. Первичная структура полиэдрина нескольких ВЯП выяснена нами ранее [2--4]. Полиэдрины представляют собой группу высокогомологичных по первичной структуре белков, степень гомологии которых лежит в пределах 82 $94 \%$ [5]. Настоящее сообщение является первой публикацией по исследованию первичной структуры гранулина бакуловирусов.

Восстановленный и карбоксиметилированный гранулин расшепляли трипсином и химотрипсином. Методами гель-фильтрования, ионообменной хроматографии на $\mathrm{AG}-50 \mathrm{X}$ $X 8$, высоковольтным электрофорезом и хроматографией на бумаге, описанными нами ранее [3, 4], было получено 22 триптических и 34 химотриптических пептида. $\mathrm{N}$-концевую последовательность пептидов определяли методом Эдмана, как описано нами ранее $[3,4]$.

При сопоставлении триптических и химотриптических пептидов удается выписать 26 фрагментов с уникальной аминокислотной последовательностью, насчитывающих в сумме 212 остатков аминокислот, что составляет $91 \%$ полипептидной цепи белка с молекулярной массой 27500 [1].

1. Ser-Gly-Lys-GIu-Phe-Leu-Arg-Glu-Thr-Trp-Thr-Arg-Phe-Ile-Glx- $\Lambda$ sx-Glx-Phe-Val-

$\left(\right.$ Asx $_{2}$, Ser, Thr, Glx, Pro, Met, Leu, Tyr)

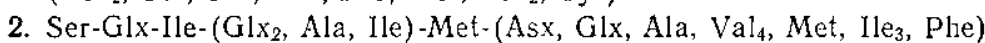

